\title{
East-West and North-South Relations
}

\author{
Tamas Szentes
}

Peace in the Third World is endangered at several levels: by the arms race on the world level, by foreign military interventions, by regional wars, by militarisation at the national level and by two 'invisible wars', namely, that which manifests itself in mass misery and hunger; and that which has brought about the deterioration of the natural environment and the exhaustion of non-renewable natural resources.

European colonialism made such a lasting impact that many local wars and regional conflicts still have their roots in the colonial legacy: particularly those stemming from boundary problems, separatist movements, and manipulated nationality or religious divisions. Cultural colonialism is responsible for the erosion of many valuable cultural traditions and thereby for the loosening of the forces of intra-society cohesion. And the 'invisible war' against poverty and hunger is mainly the consequence of the socioeconomic structures which have developed in the peripheries of the capitalist world-economy.

Over and beyond this historical responsibility of Europe for colonialism and the rise of the centreperiphery relations, let us see how post-World War II developments and the split of Europe into two groups of countries with opposite socioeconomic systems have influenced the peace and security of the Third World, and how the resulting East-West conflicts have interacted with conflicts between the global economic centre and its peripheries.

However, we need to be cautious when using the concepts of 'North-South' and 'East-West' relations, which are terminological simplifications that can sometimes conceal or even falsify the underlying social relationships. Neither term is interpreted by international journalism and political science to refer to specific geographical regions. Rather, they are used to characterise differences, on the one hand, in the level of economic development, and, on the other, in types of social system. By applying different criteria to the various parts of the same world, these classifications conceal system specificities such as those within both the 'North' and the 'South' as well as development differences within both the East and the West. Another ambiguity is that usually the 'East' includes only the socialist countries which belong to the Warsaw pact, while the 'West' is applied to all the developed capitalist countries, whether they are members of NATO or not.

Cent re-periphery relations can be reduced neither to colonialism nor to the quantitative 'development gap' between advanced and underdeveloped countries. They involve functional relations of asymmetrical economic dependence in various forms, which are supplemented by or provide a basis for foreign political, military, technological and cultural influence. As the centre-periphery dichotomy stems from the uneven development of the capitalist world-economy, and is rooted in the unequal structure of the worldwide social relations of production, the conflicts which derive from it, both between the centre and periphery and within the latter, cannot be fully solved without structural and institutional changes and without a substantial modification of production relations on a world level. Normally these conflicts take the form of conflicts between countries or groups of countries. The central issue seems to be national sovereignty, not only in the political and legal, but also in the economic and cultural senses. As a result, primarily national interests seem to confront each other. Nevertheless behind these national interests there are different social or class forces, standing to benefit or lose from the prevailing structure of centre-periphery relations.

The historical contradiction between capitalism and socialism originates in the capital-labour antagonism of the world capitalist system, i.e. from the dominance of accumulated 'dead' labour, capitalised by a class, over the 'live' labour of others. Socialism in theory would emancipate labour, i.e. eliminate the dominance of capital and introduce a single rule of distribution according to labour in the whole society. However, as

IDS Rullctin. 1985. vol 16 no 4. Institute of Development Studies. Sussex 
a consequence of uneven development within the world capitalist system, socialist transformation orginated neither directly at the world level nor in the developed countries. Instead, it first started in individual less developed, peripheral or semiperipheral countries. Their socialist development has been inseparable from the struggle for national emancipation and has in consequence been modified. And since the rise of socialist systems within a national framework also implied changes, but only partial ones, in the global system, the dialectics of mutual effects necessarily modified both capitalist and socialist systems.

Though East-West relations are represented as a conflict between socialism and capitalism, materialised in two groups of countries, i.e. as a class conflict centred around the issue of social emancipation, in reality, and despite all the system-differences, procapitalist or pro-socialist forces are not allocated according to national or 'bloc' frontiers. Moreover, national interests often interfere with, reinforce or weaken conflicting social class interests. Thus identification of the historical struggle between capitalism and socialism with the conflict between two groups of countries, in particular, between the two military 'blocs', is an inadmissible over-simplification.

During the Cold War a sort of negative-sum-game has developed of which the arms race is but one element, though undoubtedly the most decisive. While the Cold War itself did not originate solely in system-conflict, but also in the context of centre-periphery relations and in reaction to Third World nationalism, it has directly and indirectly affected the development and the security of the Third World. It has done so by exteriorising the East-West confrontation, thus reinforcing the process of militarisation in the Third World. In addition, it has transplanted the development patterns which arose in the two Europes under cold war conditions. These have neither followed, in the case of Western Europe, simply from the 'pure logic' and inherent tendencies of the development of capitalism, nor have they followed, in the case of Eastern Europe, merely from those of the socialist transformation. They have also reflected the impact of the Cold War itself and have thereby reinforced tensions and conflicts within and between Third World societies as well.

It would be too easy, but hardly well-founded, to present not only the Third World but also Europe as victims of the superpower game. The paradigm of 'bipolarism', which identifies the historical st ruggle of the two social systems with the confrontation of the two military blocs is itself a product of the Cold War. It is misleading not only because of its oversimplification of the historical contradiction of social systems and the actual differences between the two superpowers; but also because of its neglect of the interactions between East-West and North-South relations and their effects upon internal changes within the Third World, including the effects of the latter in turn upon the superpowers' own policies not to mention the role of other European powers in East-West and North-South relations.

The Cold War confrontation which developed after World War II thus partly reflected and partly induced the divergence between Eastern and Western policy toward anti-colonial liberation movements. Since then, practically all political changes within the Third World have been reinterpreted in the context of a bipolar world, as shifts in East-West power relations, thereby calling forth reactions by the major powers. In Third World societies this polarisation of very diverse political forces according to Eastern or Western orientation, has aggravated the consequences of internal disintegration, has often opened new sources of conflict, has hindered national integration and has obstructed regional cooperation.

Owing to the linkages between domestic and global political forces, minorities have found it easier to seize state power in many Third World countries. This refers not only to puppet regimes established in the process of decolonisation by neocolonial forces, but also to the many other regimes arising from coupsd'état and political instability, which have sought external backing. The external relations of internal political forces have become a part, often a decisive one, of the domestic power game.

What is worse is that under the protection of foreign powers, political regimes feel much less need to form domestic alliances and to make constructive compromises with the forces of opposition. This often gives rise to a tendency toward over-radicalisation which in many cases is aggravated by the real or assumed fear of military intervention by the opposite foreign power. This over-radicalisation leads, as a rule, to unrealistic economic policies, to the over-politicisation of social and culture life, to coercive, administrative methods of conflict management, to an over-expansion of the security forces and to an excessive role of the state and within it, of the army.

In this context there are, of course, substantial differences between left-wing and right-wing regimes. Yet all too often the former try to reach goals which would otherwise be beneficial without democratic participation and contrary to given conditions of reality. Furthermore, over-radicalised and antidemocratic left-wing regimes also aggravate social tensions and can all too easily pave the way for rightwing government. 
East-West polarisation also creates obstacles to regional integration or cooperation in the Third World, supplementing the divisions stemming from the colonial legacy, such as the boundary conflicts and the divergences brought about by cultural, linguistic, commercial and monetary ties with different colonial metropolises. Marked asymmetries deriving from the latter have been partly replaced - or rather complemented - by a pattern hardly less asymmetric. If some countries in a region reorientate their trade and communication towards the East, demonstrating the chance for the others to do the same, this contributes to the diversification of international relations, widens the developing countries' room for manoeuvre, improves their bargaining position and may provide a way out of economic blackmail and political pressure from the West. Nevertheless, it remains based on uneconomic long-distance communication and it may impede intra-regional cooperation. Thus it is hardly the most rational way in which to restructure the international division of labour.

In spite of all the benefits developing countries gain from technical assistance, and despite their improved bargaining position after the ending of former colonial monopolies, the influence of foreign experts and the training abroad of the first generations of the intelligentsia, often have disintegrating effects especially when East-West rivalries are transferred to the country or region concerned. Differences in the education of the elite within a region or the successive generations of the national intelligentsia do not promote social cohesion.

The divided, heterogenous and outward oriented nature of domestic political forces in developing countries has provided many opportunities for foreign powers to manipulate them against each other, even independently of East-West competition. An obvious example is when weapons are sold by the same military power or by allies within the same military bloc to both the government and rebel forces in a developing country or to countries waging a local war against each other. Support to opposed forces in Third World countries has often been related to rivalries within the West itself, and not to the East-West confrontation.

Under these conditions it is much easier for armed conflicts in the Third World to spread. Since the Second World War there have been well over a hundred regional or local wars in the Third World [Kende 1980], many of which have also been linked to the East-West confrontation, either in the sense of having been stimulated by arms exports, or in the sense that armed conflict has been displaced from Europe (where a direct military clash would cause a nuclear holocaust) to the Third World. These so called 'limited' local wars have in reality caused enormous damage to human life, to productive capacities, to economic and social infrastructures and to the natural environment.

The gravest consequences are suffered by the least developed countries, due to their smaller 'loadbearing' capacities, and to the structural specificities of their 'underdeveloped', peripheral economies [Szentes 1983]. The growth of the military sector tends to intensify structural distortions and thereby to reinforce external economic dependence - being accompanied by balance of payments problems, cumulative indebtedness and inflation, Insofar as it also tends to be associated with the growth of the 'modern' enclave sector, hindering the transformation of the 'traditional' sector, by extracting surplus and resources from the rural economy, it also reproduces socioeconomic disintegration.

There are, of course, great differences in the actual role played by the army in these countries: whether it acts as the protector of the interests of ex-colonial or neocolonial powers and their local allies, or as the protector of national sovereignty and the pioneer of nation-building and development. Hence the economic and socio-political performance of military regimes varies greatly [Wolpin 1981]. A sharp distinction has, indeed, developed between progressive, populist, leftist military regimes and reactionary, rightist military dictatorships, often associated with support by different foreign powers. In spite of these variations, however, it is arguable that military governments of both the left and the right, are more coercive, less responsive to the demands of their own people and less capable of organising development than their civilian counterparts.

The Cold War confrontation has also left its mark on the development pattern chosen by developing countries. The latter's orientation towards the East or the West has often implied the adoption of appropriate 'models' of development from Eastern or Western Europe which in turn reflected the abnormal conditions of the Cold War. The Western model is organised to highlight the superiority of the capitalist economies over the collectivised ones of the 'East', contrasting Western consumerism with Eastern producerism, while still relying on the cheap resources of the Third World. It has built up a consumer society, whose development, despite its linkages with a Keynesian system of state intervention, has been attributed in conventional theory and in dominant ideology to a now extinct laisser-faire capitalism. The new technologies which resulted from the post-war, or rather war-induced revolution of science and technology, and which reflected the prevailing factorendowments of the most advanced countries in the 
West, were mistakenly regarded as applicable in all countries of the world

There is no need to explain in detail how disastrous efforts to copy this model in the Third World - under conditions substantially differing from those in the West - have proved to be. All too often the demonstration effects of business-manipulated Western consumerism have induced local elites to increase their demands for luxurious imports or to implement policies of import-substituting industrialisation. The consequent economic disequilibria have been manifested in high inflation and indebtedness, the widening of rural-urban gaps, the acceleration of social differentiation, the marginalisation of the masses and the alienation of a narrow elite, leading to an explosive accumulation of social tensions.

As regards the Eastern European model, which also became the object of imitation in a few countries, it actually reflected that early stage of socialist transformation of Eastern Europe in the 1950s. In addition to fundamental changes in ownership relations, in socioeconomic structure and in the class content of political power, the latter was also characterised by cold war isolationism, autarchic economic policies, over-centralisation, forced industrialisation, prioritisation of heavy industry, an artificially high rate of accumulation and quantitative growth, over-restriction of market forces, detailed central planning, an expanding bureaucracy and overall state control in all fields of social life.

Social reality in Eastern Europe itself, however, has moved on since that time. Both theory and practical policy have revised the model of the 1950s. The latter had been in sharp contradiction to classical Marxist ideas about social self-management and the ultimate fading-away of the state. However, it has continued to influence the ideology and political practice of all too 'socialist-oriented' developing countries. Many of these have found themselves copying an inappropriate model of socialist transformation as a consequence of trying to break away from the capitalist worldeconomy, despite their strong structural ties with it; or forcing the pace of accumulation and industrial investment, despite low income levels and rural underdevelopment; or centrally planning economic activities without the required basis of information. This copying of inappropriate models has understandably led to very unfavourable consequences which have included trade and payment imbalances, serious production bottlenecks, severe shortages of basic consumer items and the proliferation of state bureaucracy and of administrative regulations. The problems have sometimes been so severe that they have undermined the social and political base of the regime.
Third World counteractions to the polarisation between East and West and to the imposition of inappropriate development models, have on occasion been just as one-sided and irrelevant. They have sometimes manifested themselves in a sterile Third Worldism, turning against modernisation, industrialisation and urbanisation and refusing all the results of European culture, science and technology. The simple substitution of a North-South bipolarism for the EastWest one, irrespective of the differences in social systems within each, is clearly inadequate. It also neglects the interactions between North-South and East-West relations which are such a crucial component of the current crisis. Despite the historical importance of the Declaration and Action Programme to establish a New International Economic Order (NIEO), these documents and the related UN negotiations seem to have reflected an inability to understand and take account of such interactions - an inability which in part explains the failure of NIEO itself.

On the other side of the coin, the relatively short-lived and inconsistent process of détente was largely confined to Europe with hardly any attention being given to possible implications for the 'South' though there have of course been some exceptions, such as the Reports of the Brandt Commission, or the Soviet proposal to devote part of the financial resources released by military reductions to development assistance. Yet détente brought about important changes in East-West relations, some of which have proved irreversible. The 'iron curtain' between the two Europes has been gradually lifted, diplomatic relations, including those between the two Germanies, have been normalised, tourism has developed, and in many fields economic, technological, scientific and cultural cooperation between Eastern and Western European countries has been achieved. Hence even the dramatic worsening of relations between the United States and the Soviet Union in the late 1970s and early 1980s has not led Europe back to the Cold War. Nevertheless detente failed to break the image of bipolarism on both sides. Political changes originating in the context of centre-periphery relations continued to be conceived as shifts in the East-West struggle. National movements and liberation struggles in the Third World still tended to be viewed in the West as one-sided successes for the Soviet Union. As a result of being interpreted as violations of agreed principles, they soon undermined the basis for Soviet-American detente.

Demands for a NIEO, in sum, tended to be viewed by the major capitalist powers either as an East-backed attack against the West or merely as a Third World issue. At the same time the South was inclined to interpret détente and East-West rapprochement as a 
sign of the unity of the North, or at least as a compromise at the expense of the South, something which would weaken its bargaining position.

But the zero-sum-games of East-West and NorthSouth relations have been in fact negative-sum-games. This has become ever more apparent in the light of the present global crisis. Thus if both sides in Europe wish to contribute positively to the peace and security of the Third World, their task is 'not simply to return to the path of Helsinki, but to return to the path of a new world order' [Janos 1983: 12] that is, they must not only promote peaceful intraregional cooperation between countries of different social systems and the mutual disintegration of the two military blocs. They must also work for the gradual elimination of centreperiphery relations, national emancipation and social progress in the Third World, and the establishment of a new, democratic and demilitarised world order.

\section{References}

Janos, Peter, 1983, 'Some lessons of the preparation for the Helsinki Conference', Hungarian Siudies on Peace Research, Budapest Academy of Sciences

Kende, Istvan, 1980, 'Local wars 1945-1976', in Asbjorn Eide and Marek Thee (eds), Problems of Contemporary Milirarism, Croom Helm, London

Szentes, Tamas, 1983, 'Economic effects of global militarisation', Development and Peace, vol 4 no 1

Wolpin, Miles D., 1981, Milinarism and Social Revolution in the Third World, Landmark Studies, Allanheld Osmun, Montclair (NJ) 